\title{
The Relationship Analysis of e-Government Implementation on Increasing Capital Investment in Region (Case Study : Banyuwangi City)
}

\author{
Beny Prasetyo ${ }^{1}$, Tony Dwi Susanto ${ }^{1}$
}

\begin{abstract}
In recent years, the investment climate in Indonesia is increasing, where the realization of capital investment projects in the first quarter of 2014 reached IDR, 106.6 trillion. The increased capital investment can not be separated from the investment attractiveness in Indonesia. Some traditional factors are labor, infrastructure, ecoonomic, social and political, while ICT factor which have influenced on shaping investment attractiveness is e-government of host country. This research will analyze the relationship between e-government implementation at local government level (city) as one of the strategies to realize good governance. With good governance will influence the investors to come for invest. To answer this research, researcher used a qualitative approach with a single case study is Banyuwangi City in East Java Province, Indonesia. Case study used to explore more details about this research topic. The results of this study are e-government implementation have impact on the improvement of good governance quality and increasing investment value.
\end{abstract}

Keywords--E-Government, Good Governance, Capital Investment.

\section{INTRODUCTION}

$I^{n}$ recent years, the investment climate in Indonesia is increase. Based on data from The Investment of Coordinating Board of the Republic Indonesia (BKPM) in 2014, the realization of capital investment projects in the first quarter (January-March) of 2014 is IDR. 106.6 trillion, and the third highest since the third quarter of 2013 exceeded IDR. 100 trillion. Total Domestic Direct Investment (DDI) realization is IDR. 34.6 trillion, while the total of Foreign Direct Investment (FDI) realization amount IDR. 72 trillion [1].

The increased value of capital investment can not be separated from the investment attractiveness that attract the investors, both domestic and foreign [2]. Some factors which can create the investment attractiveness are labor factor, infrastructure, cost, economic, market size, government regulatory, political, and social and culture [3],[4].

Along with technology development, investors' decision to invest in a country is also influenced by the Information, Communication and Technology (ICT) capability in particular e-government implementation of the host country [5],[6]. The benefit of E-government implementation are bureucracy reformation, corruption reduction, transparency and accountability improvement [7],[8]. Good governance and good economic climate will increase FDI and DDI. Good governance is an important factor for promoting FDI which include the efficiency of administration public, the efficiency regulation, lower corruption and transparency in government.

\footnotetext{
${ }^{1}$ Beny Prasetyo and Tony Dwi Susanto are with Departement of Physics Engineering, ITS Surabaya, Indonesia. E-mail: beny14@mhs.is.its.ac.id; tonydwisusanto@is.its.ac.id.
}

According previous introduction, this research analyzed the impact of the e-government implementation in local government (city). The implementation will influence the investors to invest in region/city. To answer this research, a qualitative approach based on single case study is used.

\section{THEORY}

\section{A. Electronic Government (e-Government)}

E-government related to the use of information technology (such as the wide area network, internet and mobile computing) by government that has the ability to built relationship with citizens, business and other organizations [9].[10] defines e-government as a way of the government's most innovative for using Information, Communication and Technology (ICT), particulary webbased applications to provide and facilitate the citizens and business sectors to access government information and services more easily.

\section{1) The Benefits of e-Government}

Implementation of e-Government will have an impact to reform of e-Government bureucracy better, increase the efficiency of bureucracy, decrease number of corruption, increase transparency and accountability, are some of the benefits derived from e-government. The others benefits from implementation of e-government are improve public services to the citizens, and reform the business process technology-based (online).

Deloitte Research Group [11] described the government strategy through implementation of e-government potential to reduce time, effort and costs to be incurred by the citizens and the business sectors to find out about the rules and regulations of the government. There are some advantages from the implementation of e-government, so that becomes motivation for the government to make e- 
government as a tool to reform the government. Some of the benefits of e-government is often the reason and motivation for the government to use e-government include: efficiency, marketization, new and improvedservices, decentralization, administrativecontrol, citizen demand, increased citizen participation, transparency, and economic development [12].

According to Azubuike [13], there are five reasons why egovernment can help investors in making decisions before to invest (FDI) include: (1) will increase the knowledge of investors about the environment includes market segment and econommic conditions (2) reduce uncertainty about the possibility of rules changes and the administration of the business environment, (3) increase the transparency of financial transactions involving government staff and nongovernment, (4) contribute to create the image of country and influence the perseption of investors, (5) contribute the data and perspectives on how the investment project can be implemented and managed.

\section{B. Good Governance}

Referring to definition of good governance according to World Bank that good governance is a way where the use of power in management of economic and social resources for development. Furthermore, according to Kaufmann [14] defines good governance is the governance of government oriented on principle voice and accountability, political stability, government effectiveness, regulatory quality, rule of law and control of corruption. Another definitions of good governance by TUGI [15] is the ability and capability of the government to participatory, transparent, accountable, effective and efficient, and fair enforcement of the rule and law.

Good governance is an important factor for promoting Foreign Direct Investment (FDI) which include the efficiency of public administration, efficiency regulations, low levels of corruption and transparency in government . Good governance practice gives more public trust to government [16], improve organizational performance [17], increase the decision-making process by top level management [18], [19], create good climate investment attractiveness [20] to attract investor foreign to invest.

\section{Capital Investment}

According to Law Number 25 of 2007 on Capital Investment, capital investment is defined as a form investment activity by both domestic investors and foreign investors to do business in the territory of the Republic of Indonesia. According to Law Number 25 of 2007 on Capital Investment and confirmed again through Regulation of the Investment Coordination Board the Republic of Indonesia Number 5 of 2013 on guidlines and procedures for licensing and non-licensing of investment, investment $\mathrm{s}$ in the Republic of Indonesia is divided into two these are Domestic Direct Investment (DDI) also known as Penanaman Modal Dalam Negeri (PMDN) and Foreign Direct Investment (FDI) also known as Penanaman Modal Asing (PMA).

According to Law Number 25 of 2007 on Capital Investment and confirmed again through Regulation of the
Investment Coordination Board the Republic of Indonesia Number 5 of 2013 on guidlines and procedures for licensing and non-licensing of investment, Domestic Direct Investment (DDI) is investment activities to conduct business in territory of the Republic of Indonesia by domestic investors using domestic capital.

According to Law Number 25 of 2007 on Capital Investment and confirmed again through Regulation of the Investment Coordination Board the Republic of Indonesia Number 5 of 2013 on guidlines and procedures for licensing and non-licensing of investment, Foreign Direct Investment (FDI) is investment activities to conduct business in territory of the Republic of Indonesia by fully foreign investors or joint with domestic investors

\section{METHOD}

This research was taken in Banyuwangi City. The data was collected from three departments, namely Badan Pelayanan dan Perizinan Terpadu (BPPT), Dinas Perhubungan Komunikasi dan Informatika (Dishubkominfo), Badan Perencanaan Pembangunan Daerah (BAPPEDA). The other data source was collected from three investors, SMEs investor is Nagud! Banyuwangi, medium investor is Osing deles and largescale investor is Santika Hotels Banyuwangi. The research flow are presented in figure 1 .

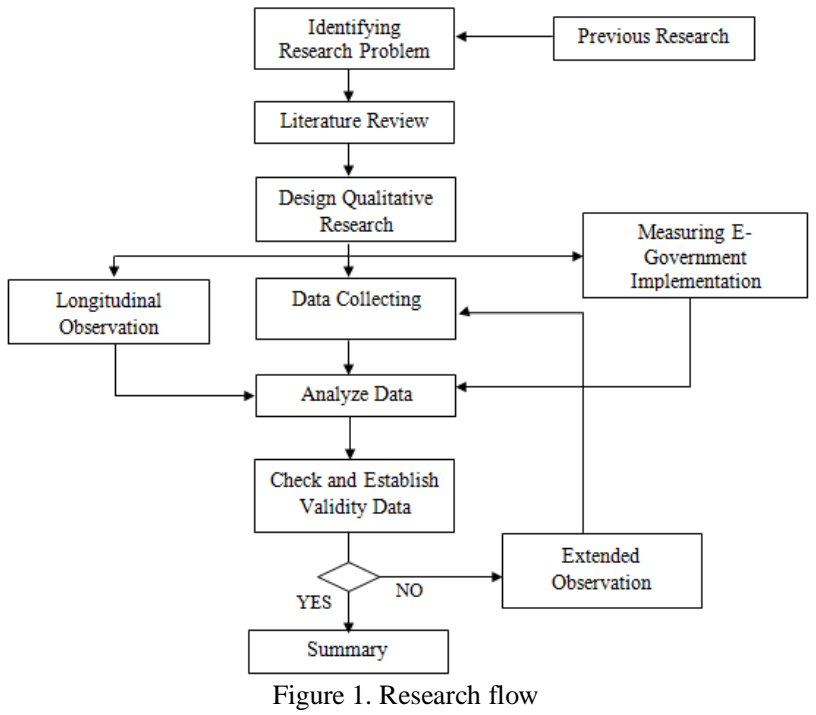

According figure 1, longitudinal observations is to find the improvement of capital investment value, egovernment, and good governance before and after the egovernment implementation massively. Furthermore, according Yin, data anlysis technique consisted of pattern matching, explanation building, and time-series analysis.

\section{CONCEPTUAL MODEL}

To construct a qualitative research, it begins with literature review, to find the conceptual model of this research. The conceptual model are presented in figure 2 below. 


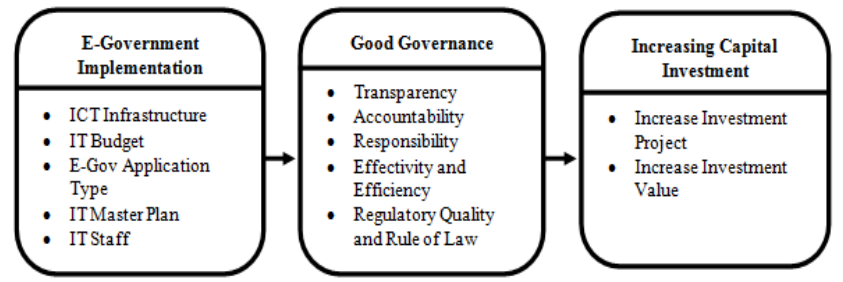

Figure 2. Conceptual model

This research consists of three domain: e-government implementation, good governance, and increasing capital investment. E-government implementation consisted of several indicators these are ICT infrastructure, IT budget, egovernment application type, IT master plan and IT staff. Yet, dimensions of good governance consisted of transparency, accountability, responsibility, effectivity and efficiency, and regulation quality.

Furthermore, we made early propositions that used for the guidlines for collecting data, those propositions are:

P1: e-government implementation at the local government will create good governance.

P2: good governance at local government will increase the investment attractiveness, so the capital investment will increase.

P3: The investors prefer to choose a region with better e government implementation.

\section{RESUlt AND DISCUSSION}

\section{A. Interviewee Profile}

In this research, we used 7 interviewee they are: (1) Abdullah Azwar Anas, M.Si as Major of Banyuwangi; (2) Ilzam Nuzuli, S.E as Head of Capital Investment Department in BPPT; (3) Agustinus Suko Basuki, S.T as Head of Information Technology Department in Dishukominfo; (4) Joni Priyanto, S.ST as Head of Electronic Data Management Department in Dishubkominfo; (5) Annisa Febby Chaurina as Owner Nagud; (6) dr. Zunita Ahmadah as Owner Osing Deles and (7) S Hadi Putra, S.Psi as HRD Manager of Santika Hotel Banyuwangi.

\section{B. Longitudinal Observations Results}

1) e-Government Implementation Longitudinal Observation

Based on ICT infrastructure longitudinal observations in Banyuwangi between before and after the implementation of e-Government massively the year 2011 had many improvements such as improved network connectivity of fixed Internet where prior to 2011 only $40 \%$ SKPD are connected to a wireless LAN, and now all SKPD, and 95\% of the village. Bandwidth that used to only $4 \mathrm{MB}$ is now increased to $200 \mathrm{MB}$. In terms of wireless network, wifi network before the year 2011 has not been dispersed thoroughly to SKPD, but the 2015 point wifi (@ wifi.id) as much as 1400 points have been spread throughout government offices, hospitals, schools, green space, and other public spaces.

Furthermore, in terms of e-Government application, the author divides into eight components consisting of: (1) The total number of applications / e-Government services, (2)
Number of data integration application (data sharing), (3) the number of internal service applications (4) the number of public services applications, (5) the application with transparency function, (6) an application with the accountability function, (7) the application with responsiveness function, and (8) the application with effectiveness and efficiency of service function.

Observations obtained prior to 2011 the number of egovernment applications was 20 applications, and after the year 2011 increased to 35 applications. In terms of data sharing application, prior to 2011 no one application that has the function of data sharing, but after the year 2011 there were 9 integrated applications. In terms of applications for internal services, prior to 2011 there were 18 applications, and after the year 2011 as many as 17 applications. Furthermore, from the public service application prior to 2011 there were only 2 applications, and after the year 2011 increased to 16 applications. From the application with transparency function, before 2011 no application that serves for the transparency of financial and policy, but after the year 2011 there were 9 applications and one government website which has a transparency function. From the responsiveness application function, prior to 2011 there is no application that has responsiveness function, whereas after 2011 there 4 applications. In terms of effectiveness and efficiency of bureaucracy, prior to 2011 there were 20 applications and after the year 2011, there were 24 applications.

\section{2) Good Governance longitudinal observation}

Good governance indicators used in this study include: transparency, accountability, responsivity, and effectivity and efficiency of bureucratic.

\section{- Transparency}

In terms of financial transparency, the government has reported all reports starting from planning, financial management and accountability through the website www.banyuwangikab.go.id area. Moreover, Budget Transparency Festival since 2014 is useful to present the data and financial information to the public area. In terms of the rules transparency, the government has had a whole service for publication rules through JDIH service district or province.

\section{Accountability}

From liability side of the budget, e-government implementation in the form of financial applications integrated with the government's website easier for the government to provide accountability reports through the website www.banyuwangikab.go.id. In addition, after the year 2011 has been set up PPID to facilitate a detailed report related to the government's financial budget for public.

In terms of performance accountability of government, implementation of LPPD and LPPDes system for data collection and performance evaluation of government officers to facilitate the collection of accountability and performance reports of government agencies (LAKIP). While the performance reports available on their website www.banyuwangikab.go.id. 


\section{- Responsivity}

The first responsiveness is about criticism and suggestions. Prior to 2011 there is no complaints service, but after the year 2011, Banyuwangi has provided complaints services based website and SMS centers that make governments responsive to public complaints.A second responsiveness is about service. Government launch of several public service applications such as Deed Online, SIPO which provides speed in the public service.

Bureucratic Effectivity and Efficiency

In the case of public service bureaucracies, before the year 2011 some existing applications works for internal services so that public service is not good because there is no system / application. After the year 2011 since the implementation of some online services makes the procedure of bureaucratic public services faster and easier.

In terms of internal management, prior to 2011 the lack of integrated financial system makes the financial and asset management is still difficult and not optimal. In terms of service evaluation, monitoring cannot be done because the service process is offline. In terms of monitoring HR performance is also difficult because there is no application of e-Performance. After the year 2011, where most services are already online, the government can discover and evaluate services process easily. Financial management, asset and others are good because it is systematically and well integrated. HR performance evaluation can be done via e-Performance easily.

3) Capital Investment Longitudinal Observation

Investments values in Banyuwangi from 2010 until the first quarter of 2016 as in the table 1 below:

TABLE 1. CAPITAL INVESTMENT REALIZATION IN BANYUWANGI.

\begin{tabular}{ccccc}
\hline \hline \multirow{2}{*}{ Year } & \multicolumn{3}{c}{ Investment Value (in Rupiah) } & \\
\cline { 2 - 4 } & $\begin{array}{c}\text { PMA } \\
(\mathbf{0 0 0 . 0 0 0 )}\end{array}$ & $\begin{array}{c}\text { PMDN } \\
(\mathbf{0 0 0 . 0 0 0})\end{array}$ & $\begin{array}{c}\text { Local } \\
\text { Investment } \\
(\mathbf{0 0 0 . 0 0 0})\end{array}$ & $\begin{array}{c}\text { Total } \\
(\mathbf{0 0 0 . 0 0 0})\end{array}$ \\
\hline 2010 & 9.455 & 17.800 & 245.357 & 272.612 \\
2011 & 959.325 & 803.866 & 350.356 & 2.114 .640 \\
2012 & 83.048 & 645.248 & 441.217 & 1.169 .514 \\
2013 & - & 2.450 .018 & 937.366 & 3.387 .384 \\
2014 & - & 2.345 .246 & 1.099 .721 & 3.444 .968 \\
2015 & 6.983 .200 & 299.596 .200 & 1.206 .475 .069 & 1.513 .054 \\
Q1 2016 & 21.066 .428 & 271.807 & 329.709 .171 & 622.583 .199 \\
\hline \hline
\end{tabular}

\section{Data Analysis using Case Study Approach}

After longitudinal observation, case study analysis is further conducted in two step namely pattern matching and explanation building.

\section{1) Pattern Matching}

The first analysis stage is pattern matching. Pattern matching is done by comparing the predicted pattern that builds based on theory with the actual pattern identified based on findings. There are two steps in patter matching:

\section{- Identifying Prediction Pattern}

Based on the theory of some literature, a prediction pattern of this study presented in figure 3 below.

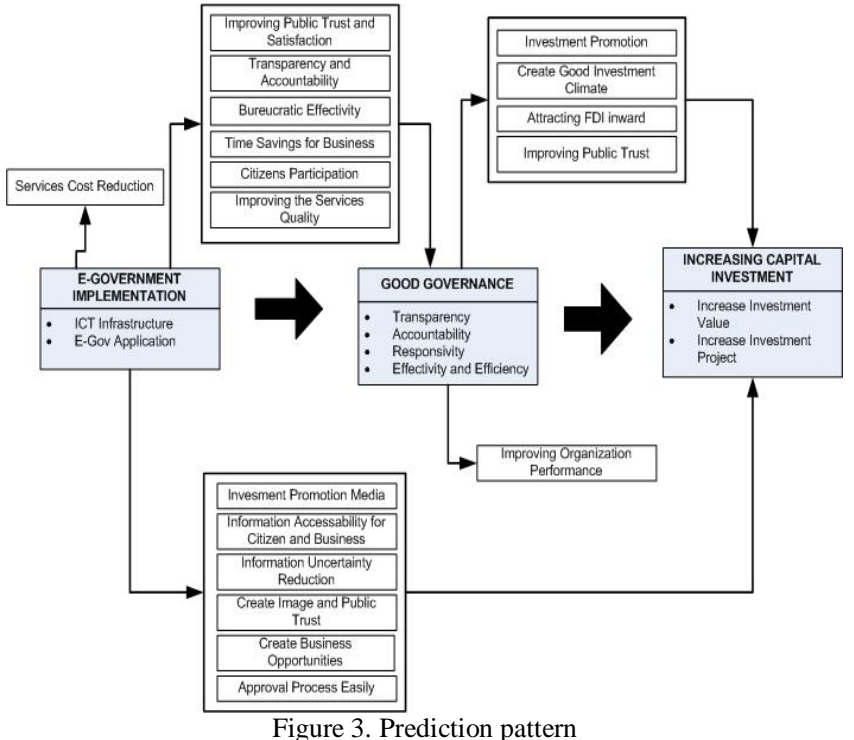

\section{- Identifying Actual Pattern}

From the prediction pattern, some interviews conducted to identify the findings. The findings can fit a prediction pattern or different with the prediction pattern that has been made. Based on the interview, here are the results of predicted patterns identification show in the image below:

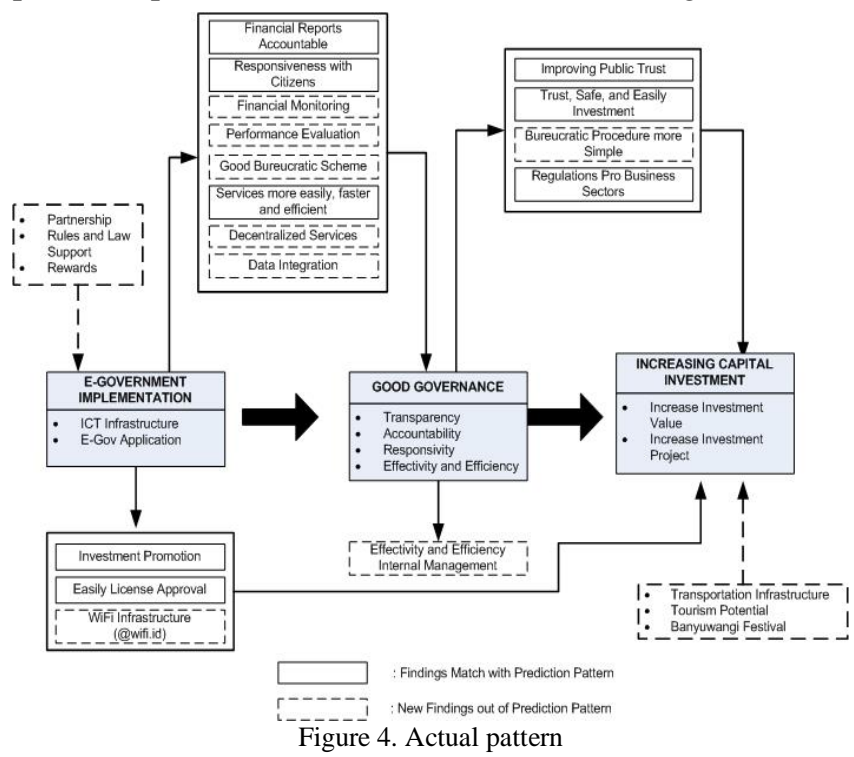

Based on the actual pattern, can be explained as follows: First, the partnership role with private companies in provision of ICT infrastructure, support the regulations and policies in giving reward which has a significant impact on the sustainability of the e-government implementation in Banyuwangi. Second, the e-government implementation in Banyuwangi given an impact on increasing the quality of good governance such as to make a decentralized egovernment services, monitoring financial transactions easier, more transparent and accountable, well bureaucracy, and make service faster and easier. Third, the benefits of improving the governance quality has influence the public trust, security and comfortability for the investor to invest, bureaucracy service helped the attractiveness of investment in Banyuwangi which have an impact on increasing investment values. Fourth, the e-government 
implementation as a tool for investment promotion and also the availability of infrastructure wifi (@ wifi.id) has a role in increasing the attractiveness of investment in Banyuwangi. The next benefit is the discovery of several new investment attractiveness factors in Banyuwangi include: transport infrastructure, tourism, and Banyuwangi Festival event.

\section{2) Explanation Building}

After the actual pattern is identified, proposition improved. Here is an improved proposition of the study.

P1: Investors consider the business potential factors before deciding to invest

P2: Investors consider the factors of governance after the business potential is fulfilled

P3: The e-government implementation help in realizing good governance

P4: Good governance helps in increasing the investment attractiveness

P5: The e-government implementation has an impact on the investment attractiveness

\section{CONCLUSION}

After collecting data, longitudinal observation, and case study analysis, are found some the results of this study. The results are: (1) there is improvement of e-government in Banyuwangi government before and after initiation of egovernment massively, (2) there is quality improvement of good governance in Banyuwangi government, (3) there is investment value improvement in Banyuwangi, (4) implementation of e-government has realize good governance. Second, improving the quality of local governance will create the image and public trust among businesses which impact on investment interest. Third, egovernment implementation capable in providing accessibility of information on potential local investment for potential investors. Fourth, the role of partnership, support regulations and policies has contributed to the sustainability of the e-government implementation. Fifth, investment attractiveness formed through the availability of transport infrastructure, tourism and pro-business regulatory support.

\section{FURTHER RESEARCH}

This study use a single case study approach, multiple cases by adding another city as a case study needed for future research. The informants in this study were selected based on the scale of investment (micro-small, medium, and large) as seen from the investment values. Future investment could add categories based on the type of investment as Foreign Direct Investment (FDI), Domestic Direct Investment (DDI) and local investment.

\section{REFERENCES}

[1] BKPMRI, "Realisasi Penanaman Modal PMDN - PMA Triwulan I Tahun 2014," 2014.

[2] KPPOD, "Daya Tarik Investasi Kabupaten/Kota di Indonesia." 2004.

[3] A. R. Danciu and V. A. Strat, "Factors Influencing the Choice of the Foreign Direct Investments Locations in the Romanian Regions," Procedia - Soc. Behav. Sci., vol. 109, pp. 870-874, Jan. 2014.

[4] J. Villaverde and A. Maza, "Foreign direct investment in Spain: Regional distribution and determinants," Int. Bus. Rev., vol. 21, no. 4, pp. 722-733, 2012.

[5] T. Addison and A. Heshmati, "The New Global Determinants of FDI Flows to Developing Countries: The Importance of ICT and Democratization," 2003.

[6] A. Al-Azzam and E. Abu-Shanab, "E-government: The gate for attracting foreign investments," 2014 6th Int. Conf. Comput. Sci. Inf. Technol. CSIT 2014 - Proc., vol. 1, pp. 161-165, 2014.

[7] F. G. Mucavele, "Global Forum on International Investment," in Global Forum on International Investment, 2002.

[8] NOIE, E-Goverment Benefits Study, vol. 116. 2003.

[9] The World Bank, "Global development finance 2002 : financing the poorest countries : Country tables."

[10] Z. Fang, "E-Government in Digital Era: Concept, Practice, and Development," Int. J. Comput. Internet Manag., vol. 10, no. 2, pp. 1-22, 2002.

[11] Deloitte, Enhancing Econommic Competitiveness through eGovernment. USA: Deloitte Research Group, 2004.

[12] G. Bonham and J. Seifert, "The transformative Potential of Egovernment in Transitional Democracies," Public Manag., no. May, pp. 26-29, 2003.

[13] A. A. Azubuike, "Accessibility of Government Information as a Determinant of Inward Foreign Direct Investment in Africa," in WORLD LIBRARY AND INFORMATION CONGRESS: 72ND IFLA GENERAL CONFERENCE AND COUNCIL, 2006, pp. 1-15.

[14] D. Kaufmann, A. Kraay, and M. Mastruzzi, "The Worldwide Governance Indicators: Methodology and Analytical Issues," Hague J. Rule Law, vol. 3, no. 2, pp. 220-246, 2011.

[15] C. Heritage, "Issues Report Card Good Governance," 1997.

[16] H. Alaaraj and F. W. Ibrahim, "Does Practicing Good Governance Enhance the Public," Int. J. Sci. Res. Publ., vol. 4, no. 10, pp. 1-4, 2014.

[17] S. Fadilah, "The Influence of Good Governance Implementation to Organization Performance: Analysis of Factors Affecting (Study on Intitution Amil Zakat Indonesia)," Int. J. Soc. Sci., vol. 7, no. 1, pp. 15-33, 2009.

[18] N. Saidi and H. Yared, "Fostering Digital Inclusion The Role of ICT in Development eGovernment: Technology for Good Governance , Development and Democracy in the MENA countries," in Mediterranean Development Forum IV, 2002, no. April, pp. 1-25.

[19] T. Subasat and S. Bellos, "Governance and foreign direct investment in Latin America: A panel gravity model approach," Lat. Am. J. Econ., vol. 50, no. 1, pp. 107-131, 2013.

[20] Y. Saidi, A. Ochi, and H. Ghadri, "Governance and FDI Attractiveness: Some Evidence from Developing and Developed Countries," Glob. J. Manag. Bus. Res. Financ., vol. 13, no. 6, 2013. 